\title{
Youth talk about sexuality: A participatory assessment of adolescent sexual and reproductive health in Lusaka, Zambia
}

\author{
Tamara Fetters \\ Evans Mupela \\ Naomi Rutenberg \\ Population Council
}

Follow this and additional works at: https://knowledgecommons.popcouncil.org/departments_sbsr-rh

Part of the Demography, Population, and Ecology Commons, International Public Health Commons, and the Maternal and Child Health Commons How does access to this work benefit you? Let us know!

\section{Recommended Citation}

Fetters, Tamara, Evans Mupela, and Naomi Rutenberg. 1998. "Youth talk about sexuality: A participatory assessment of adolescent sexual and reproductive health in Lusaka, Zambia." Population Council and CARE Zambia. 
August 1998
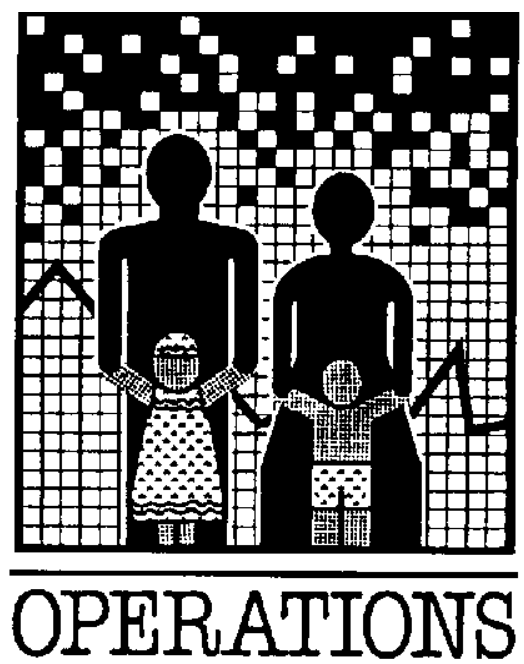

RESEARCH

TECHNICAL ASSISTANCE

AFRICA PROJECT II

THE POPULATION COUNCIL

\section{Youth Talk About Sexuality}

A Participatory Assessment of Adolescent Sexual and Reproductive Health in Lusaka, Zambia

A baseline report for an OR study testing community-based approaches for improving adolescent reproductive and sexual health 


\section{TABLE OF CONTENTS}

\section{ACKNOWLEDGMENTS}

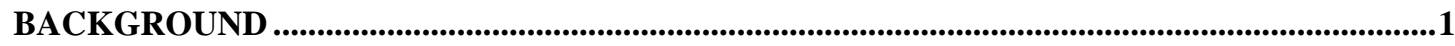

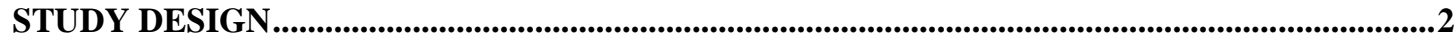

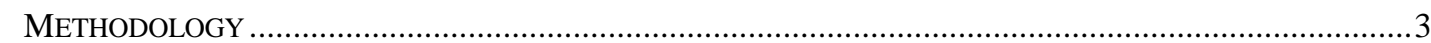

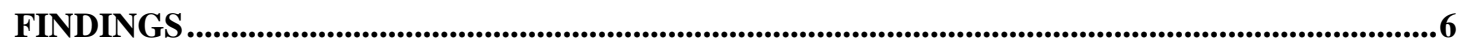

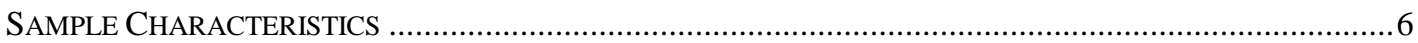

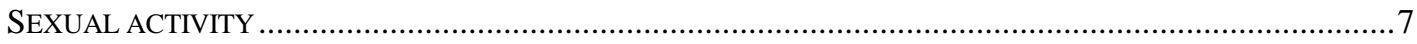

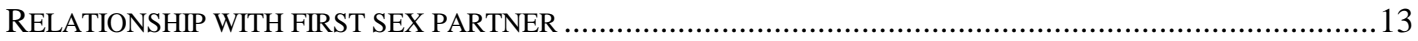

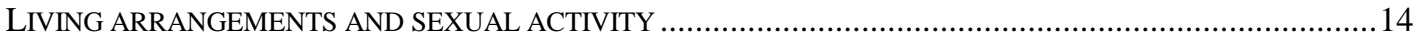

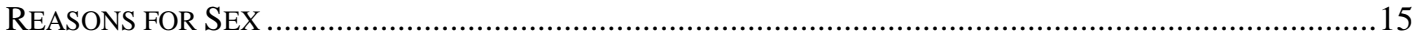

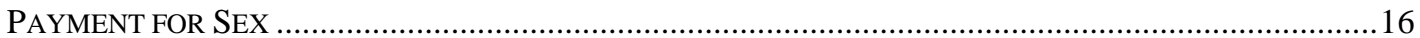

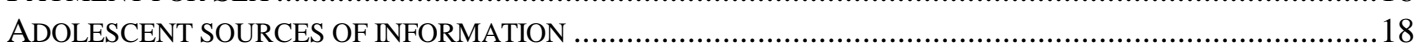

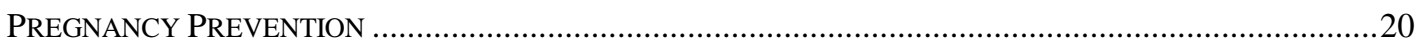

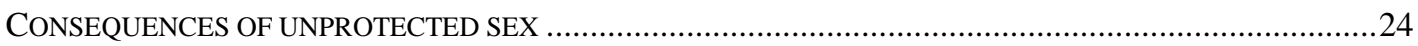

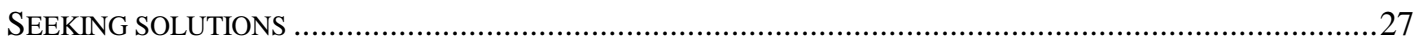

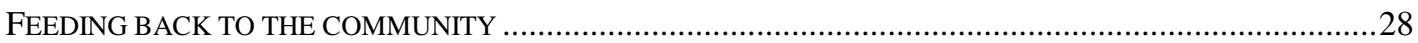

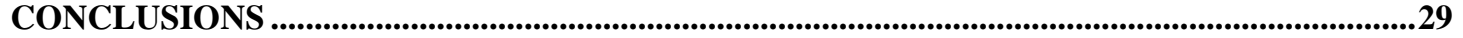




\section{Acknowledgments}

This participatory appraisal would have been impossible without the enthusiastic involvement of the adolescents of Misisi, M'tendere, Ngombe and New Kanyama Compounds. Boys and girls, in large numbers, were keen to discuss issues and actively participated in analyzing their own attitudes and behavior on sensitive subjects. This report is compiled from exercises and discussions with over 2500 adolescents. Our sincere thanks and appreciation go to all of them for their valuable contribution to the process.

We thank the Planned Parenthood Association of Zambia and Makeni Ecumenical Center, who, as partners in this project, deputed their representatives to take part in the research and help us to explore and redefine this participatory process. Also, more than fifty clinicians, Neighborhood Health Committee members, staff from CARE and other local NGOs, teachers and local church members were trained and worked with us to collect, analyze, report on, and disseminate these data in the four compounds; without their hard work none of this would have been possible. Our special thanks go to Sarah Degnan Kambou, Meera Kaul Shah, and Rose Zambezi who have supported us with ideas and encouragement, and have contributed towards refining the field methodology. We also wish to thank Alfred Ndumba for his excellent logistical support and Julie Solo from Population Council for her comments and help preparing this paper 


\section{Background}

Zambia's population is youthful, with 36 percent of its nearly 9 million inhabitants aged between 10 and 19 years (1990 Population Census). In urban areas, where almost half of the population of Zambia lives, the proportion of the population between the ages of 10 and 19 is even greater.

Not unlike adolescents everywhere, most Zambian adolescents are sexually active by their mid-teens. In a national sample of adolescents conducted by the Zambia Demographic and Health Survey (ZDHS) more that two thirds of adolescents admitted to being sexually active by age 18 . In a recent UNICEF study of 1100 school age adolescents in Lusaka, 38\% of $10-19$ year old girls and $71 \%$ of boys reported having engaged in sexual activity. When this sample was desegregated by age, the figures are only slightly lower for $10-14$ year olds, $34 \%$ of girls and $71 \%$ if boys said that they had already had intercourse. (Webb, 1997).

Pregnant teenagers have an elevated risk of maternal mortality and complications related to birth. The 1996 Zambian Demographic and Health Survey (ZDHS) found that one in five 15 year olds had begun childbearing by age 19, more that two-thirds of girls have begun childbearing. Although there are no reliable data on unwanted pregnancy knowledge about traditional methods for inducing abortion is widespread amongst adolescents in Lusaka (Kambou et al, 1997). In 1990 at the University Teaching Hospital in Lusaka it is believed that self-induced abortion accounted for up to $30 \%$ of maternal mortality, one quarter of these deaths occurred in women under 18 (Ahmed unpublished data).

In addition, sexually transmitted infections (STIs), including HIV are a major health problem for adolescents. A 1997 study by UNICEF and the National AIDS Program found that adolescents make up about 40 percent of the STI clients who present to out patient departments in Lusaka (Webb, 1997). According to the Central Board of Health, the Zambian HIV prevalence rate for adults over the age of 15 is 19.9 percent with the highest prevalence rate in the country in Lusaka where $26.5 \%$ of adults over age 15 are thought to be infected with the HIV virus (CboH, 1997). According to a 1994 sentinel site survey of childbearing women $(\mathrm{N}=11,517$ : aged 14-44) carried out in nine provinces, $20 \%$ of the sample of urban females 15-19 were HIV positive: $32 \%$ of the 20-24 year old women were infected (Fylkesnes et al, 1994). Young women in the 15 to 19 year old age group are five times as likely to be infected with HIV as boys in that age group.

In a KAP study conducted in 1990, $46 \%$ of mothers said that they were in favor of modern methods of contraception for adolescents. Despite high risk of unplanned pregnancy, unsafe abortion and STIs, only a small proportion of adolescents take action to protect themselves from pregnancy and STIs. According to the 1996 ZDHS, only 4.7 percent of 15-19 year old girls were using a modern method of contraception. No data on younger adolescents were available but it can be assumed that their use of contraception is even lower.

The numbers clearly indicate the magnitude of the sexual and reproductive health 
problems among adolescents. In addition, adolescents themselves repeatedly identify teenage pregnancy and STIs as serious health problems. However, there are many barriers to improving the situation. Adolescents encounter considerable opposition by parents and teachers to the use of modern contraceptive methods. Most adults recommend abstinence before marriage. In a study conducted in 1990, forty-six percent of mothers were in favor of modern methods of contraception for adolescents, but only 18 percent of fathers said they approved. Reasons given for these negative attitudes include concern about side effects, that use of family planning leads to prostitution, and beliefs that modern contraception can only be effectively used by educated persons (Nyirenda et al.,1990).

\section{Study Design}

In an effort to address the above problem, CARE Zambia, the Planned Parenthood Association of Zambia (PPAZ), and Makeni Ecumenical Center (MEC), with technical assistance from the Population Council's Africa Operations Research and Technical Assistance (OR/TA) Project II, are carrying out a study to test communitybased strategies that increase knowledge of, demand for, and use of barrier methods to reduce unprotected intercourse amongst out-of-school adolescents 14 to 19 years old in three compounds of peri-urban Lusaka. Participants in the intervention are either credit recipients of small loans or community counselor/commercial sales agents (CC/CSAs) of condoms who will also act as peer counselors addressing issues of reproductive health in their communities.

The ultimate objective of the study is to provide examples of successful strategies for motivating adolescents to avoid unprotected intercourse in order to reduce the incidence of unplanned pregnancies and sexually transmitted infections, including HIV. Adolescent behavior change will be measured as the prevalence of the barrier method use, number of sexual partners, family planning attitudes and measures of self-esteem and responsibility amongst adolescent participants and the surrounding community.

In order to better develop projects that address the concerns of adolescents, it is important that the situation is first understood from their perspectives. Giving the adolescents a chance to analyze their sexual behavior, reasons for the same, and how they feel their behavior impacts their lives, provides the basis for designing a project that will address the issues and concerns that the adolescents raise during such an appraisal process. In order to get a better understanding of sexuality and reproductive health from adolescents, four participatory appraisals were carried out in M'tendere, Ngombe, and New Kanyama Compounds and in a comparison site, Misisi Compound, between December 1996 and April 1997. 
Table 1: $\quad$ Population of study compounds and proposed interventions

\begin{tabular}{lcccc}
\hline Compound & $\begin{array}{c}\text { Estimated } \\
\text { population }\end{array}$ & $\begin{array}{c}\text { Estimated adolescent } \\
\text { population }^{1}\end{array}$ & Intervention & $\begin{array}{c}\text { Implementing } \\
\text { organization }\end{array}$ \\
\hline M'tendere & 71,000 & 18,673 & $\begin{array}{c}\text { micro-credit and } \\
\text { peer counseling }\end{array}$ & CARE \\
\hline Ngombe & 27,000 & 7,101 & micro-credit & $\begin{array}{c}\text { Planned Parenthood } \\
\text { Association of } \\
\text { Zambia }\end{array}$ \\
\hline New Kanyama & 15,000 & 3,945 & peer counseling & $\begin{array}{c}\text { Makeni Ecumenical } \\
\text { Center }\end{array}$ \\
\hline Misisi & 28,000 & 7,364 & control site & \\
\hline
\end{tabular}

The appraisals were conducted to address the following objectives:

- To learn about male and female adolescent knowledge, attitudes and behavior as they pertain to sexual and reproductive health; their knowledge about sexually transmitted infections and pregnancy; their sources of information; their attitudes about these issues; and their patterns of sexual behavior.

- To establish a community baseline that can be used to evaluate adolescent knowledge, attitudes and behavior over the life of the project.

- To begin to build an informed and supportive community network that can be used to sustain a community-based intervention project on adolescent sexual and reproductive health.

- To learn more about the economics and activities of adolescents' lives and how these relate to their sexual relationships.

- To allow adolescents to self-select leaders and form groups for project intervention activities.

- To "fine tune" the intervention projects based on the needs and action plans of the adolescents.

\section{Methodology}

In order to enable the adolescents to carry out their own analyses we used the Participatory Learning for Action (PLA) ${ }^{2}$ methodology. Using a variety and mix of verbal and visual tools, this methodology helps participants appraise their situations. The emphasis is on allowing the community members to identify and analyze their concerns. There are no predetermined questions and the process is left open-ended and flexible in order to follow the concerns and issues that are brought up during the research. However, leaving the process completely open-ended, especially when there are several facilitators, with varying experience using the methodology could have taken the process in all kinds of directions, depending on the special interest of the

$1 \quad$ The adolescent population is estimated at 26.3 percent of the total population, based on the 1996 Zambia Demographic and Health Survey.

2 This methodology is also known as PRA (Participatory Rural Appraisal) and PUA (Participatory Urban Appraisal) developed by Robert Chambers and colleagues at the Institute for Development Studies. 
facilitators. As a compromise, therefore, a field guide was prepared for the facilitators, which listed the main issues to be probed and analyzed during the appraisal along with a 'menu' of methods that could be used to analyze each of the issues. ${ }^{3}$ Facilitators from the community were given a short orientation to the PLA methodology and paired in groups with experienced facilitators. In this way they were learning in the field during the exercise.

The strength of the PLA methodology is in the adaptability and innovation of PLA tools to different circumstances in the field. Some of the PLA tools used are described in table 2 .

Table 2: $\quad$ Description of PLA tools

\begin{tabular}{ll}
\hline \multicolumn{1}{c}{ PLA tool } & \multicolumn{1}{c}{ Description } \\
\hline area mapping & $\begin{array}{l}\text { making a local map which includes features, resources or issues } \\
\text { important to the community }\end{array}$ \\
\hline body mapping & $\begin{array}{l}\text { participants express their knowledge of the male and female } \\
\text { reproductive system through sketching }\end{array}$ \\
\hline transect walks & $\begin{array}{l}\text { visiting a community or area systematically to observe social, } \\
\text { geographical and economic variation }\end{array}$ \\
\hline ranking and scoring & $\begin{array}{l}\text { techniques which allow participants to discuss aspects of an issue } \\
\text { systematically and reach community consensus }\end{array}$ \\
\hline sketch diagrams & $\begin{array}{l}\text { cartoons or drawings that allow participants to express their views } \\
\text { on a matter or issue }\end{array}$ \\
\hline venn diagrams & $\begin{array}{l}\text { participants make circles of various sizes to show relationships } \\
\text { among institutions in a particular setting }\end{array}$ \\
\hline focus group discussion & $\begin{array}{l}\text { a facilitated discussion of a specific topic which involves a small } \\
\text { group of people }\end{array}$ \\
\hline
\end{tabular}

In order to compile a baseline data set, with details on individual attitudes, knowledge and behavior patterns and to verify findings that some may find controversial, we decided to supplement the participatory appraisal process with a questionnaire survey conducted by the PLA facilitators. The results from this survey have been analyzed by compound and included in this report to compare with some of the key findings from the PLA as well as to be enriched by these data.

The PLAs were facilitated by teams comprised of approximately twenty members from the clinics, Neighborhood Health Committee (NHC) members, the CARE OR team, researchers from PPAZ, community development workers from MEC, trained NHC members from nearby Lusaka compounds, two CARE interns and researchers from other local NGOs. A brief training session was conducted before beginning the PLA and the survey for the new community members and then four groups were created, each of which included men and women and experienced and inexperienced researchers. The four groups often split into smaller groups, often along gender lines,

CARE Zambia has been involved in carrying out similar appraisals in other compounds in Lusaka and Livingstone as preparation for its Partnership for Adolescent Sexual and Reproductive Health Project (PALS) Project. As CARE has gained experience, the methodology has been refined and developed since the first PLA on these issues took place in Chawama Compound in March, 1997. The M'tendere PLA benefited from this experience by giving CARE facilitators the opportunity to develop a concise set of themes and issues that can be probed in the field. The field guide was developed at CARE with the assistance of an external consultant, Ms. Meera Kaul Shah. 
in the field to ensure that boys and girls could freely discuss issues related to sexual relations and reproductive health. Each group took care to meet with boys and girls, both in and out of school, and from different age groups between 10-19 years. On the first day of the PLA, adolescents in these crowded compounds came to investigate our activities and soon became engaged in the mapping activities of their compounds. They assisted us by informing their friends and neighbors about the research while we explored with them their daily activities, recreation and leisure spots. On the following days we would often find young people waiting for us with new friends, having enjoyed having their voices heard.

After carrying out the fieldwork in the morning and early afternoon, the teams would re-group every afternoon to share the day's experiences with each other and present their findings. Gaps in information were noted, information was shared and key findings were cross-checked at this time to prepare for the next day's research. Daily "process" reports were written by each team member in order to have complete documentation of the process. Before setting off in the mornings the entire group met again to review research questions and findings and to discuss appropriate methods for further exploration of these issues.

The final two days of the five-day fieldwork exercise were spent conducting individual interviews with adolescents. The same individuals on the research team were briefly trained in interviewing techniques and sent back to their respective areas in the compound to conduct interviews with a simple one page questionnaire. Convenience sampling was used in order to maximize resources; interviewers went household to household asking for one adolescent aged 10-19 per household who would consent to being interviewed until they had reached their daily quota of twenty questionnaires. At the end of the first day of the survey, questionnaires were collected and tallies were made to ensure representation from all age groups, both sexes, each of the four quartiles in the compound and in and out of school youth. A total of 1634 interviews (roughly 400 in each compound) were conducted.

The findings section of this report is based on the documentation by the teams and the discussions held during the review sessions as well as the quantitative results of the survey which were analyzed in the Epi Info software package. 


\section{Findings}

\section{Sample Characteristics}

Table 3 outlines the characteristics of the survey sample. While many similarities exist in the lifestyles and livelihoods of these adolescents and their families, the socioeconomic situations and compound infrastructure were more similar in New Kanyama and M'tendere than they were to Misisi and Ngombe. The socio-economic groups in each of these four areas, while still being classified as low, are more similar in Misisi and Ngombe than in the other two compounds.

\section{Table 3: $\quad$ Characteristics of survey sample}

\begin{tabular}{|l|c|c|c|c|c|c|c|c|c|c|}
\cline { 2 - 10 } \multicolumn{1}{c|}{} & \multicolumn{2}{c|}{$\begin{array}{c}\text { M'tendere } \\
\mathbf{n}=\mathbf{3 9 9}\end{array}$} & \multicolumn{2}{c|}{$\begin{array}{c}\text { New Kanyama } \\
\mathbf{n}=\mathbf{4 1 5}\end{array}$} & \multicolumn{2}{c|}{$\begin{array}{c}\text { Misisi } \\
\mathbf{n = 4 1 7}\end{array}$} & \multicolumn{2}{c|}{$\begin{array}{c}\text { Ngombe } \\
\mathbf{n = 4 0 3}\end{array}$} & \multicolumn{2}{c|}{$\begin{array}{c}\text { TOTAL } \\
\mathbf{n = 1 6 3 4}\end{array}$} \\
\cline { 2 - 10 } & $\begin{array}{c}\mathbf{M} \\
\mathbf{n = 2 0 8}\end{array}$ & $\begin{array}{c}\mathbf{F} \\
\mathbf{n = 1 9 1}\end{array}$ & $\begin{array}{c}\mathbf{M} \\
\mathbf{n = 2 1 4}\end{array}$ & $\begin{array}{c}\mathbf{F} \\
\mathbf{n = 2 0 1}\end{array}$ & $\begin{array}{c}\mathbf{M} \\
\mathbf{n = 2 2 5}\end{array}$ & $\begin{array}{c}\mathbf{F} \\
\mathbf{n = 1 9 2}\end{array}$ & $\begin{array}{c}\mathbf{M} \\
\mathbf{n = 2 0 8}\end{array}$ & $\begin{array}{c}\mathbf{F} \\
\mathbf{n = 1 9 5}\end{array}$ & $\begin{array}{c}\mathbf{M} \\
\mathbf{n = 8 5 5}\end{array}$ & $\begin{array}{c}\mathbf{F} \\
\mathbf{n = 7 7 9}\end{array}$ \\
\hline $\begin{array}{l}\text { Average age of } \\
\text { adolescents } \\
\text { (years) }\end{array}$ & 15.0 & 14.8 & 15.6 & 15.1 & 16.4 & 16.0 & 16.5 & 15.3 & 15.8 & 15.3 \\
\hline $\begin{array}{l}\text { Percentage of } \\
\text { adolescents in } \\
\text { school }\end{array}$ & 71 & 57 & 60 & 52 & 39 & 30 & 49 & 48 & 55 & 47 \\
\hline $\begin{array}{l}\text { Average } \\
\text { number of } \\
\text { years in school } \\
\text { (years) }\end{array}$ & 6.6 & 6.4 & 6.4 & 6.6 & 7.2 & 6.3 & 6.2 & 5.6 & 6.6 & 6.5 \\
\hline
\end{tabular}

A key factor in comparability between the compounds has to do with legalization. Misisi and Ngombe Compounds were known as "illegal" compounds in Lusaka until the past year. ${ }^{4}$ The structures here were not planned for but sprang out of the huge migratory pressure on Lusaka with the decline of the copper industry during the past twenty years. None of the houses had deeds, the rents are lower and the surrounding area is much more densely populated. The Residents' Development Committees (RDCs) in these two areas have been negotiating with the Lusaka Peri-urban District Council to accept the compounds as formal and permanent residential areas in periurban Lusaka. The roads in these two areas are nearly impassable by car. The costs in travel time are great for everyone in the household, including adolescents walking back and forth to school; there is no public transportation so marketeers must carry or hire transport to bring goods to and from the marketplace to their small ntembas (stands). Almost no public expenditures have been used on infrastructure in these two areas, there is one small primary school, no health facilities located in the compound and the poor drainage and sanitation in the areas leaves pools of stagnant water and mounting piles of rubbish (especially in Misisi). There are very few communal water

$4 \quad$ During the baseline fieldwork there were several discussions about the possibility of making this site (Misisi) the PPAZ intervention site. Unfortunately, though the need was great in Misisi Compound, the intervention NGOs felt that it was difficult to work in a compound which had just been legalized because the community infrastructure was not yet developed and the Lusaka City Council was still hesitant to commit resources to the new area. PPAZ also felt that they needed to work in an area where they already had established projects. 
taps located in either compound and Non-governmental Organization (NGO) activity is minimal compared to New Kanyama and Mtendere.

According to data in both the qualitative and quantitative portions of this research, the adolescents in Misisi and Ngombe were more likely to classify their families in a selfdefined wealth ranking as being poor rather than moderate, as was more common in M'tendere and New Kanyama. Adolescent livelihood is also different in these two areas; in M'tendere and New Kanyama adolescents are more likely to engage in small scale vending while boys from the other two areas are more likely to do daily piece work. The girls in Ngombe and Misisi are slightly more likely to engage in sex for money.

M'tendere has the highest number of primary schools which probably contributes to the higher number of boys and girls in school at the time of the interview and the similarly higher average number of years in school. Ngombe has no secondary school and only one primary school. Subsequently, not many young people continue after primary school. Approximately half of adolescents interviewed in the quantitative survey were not in school. Since these adolescents would be in the secondary grades this is often the result of having no secondary school near their homes. These students would have to go to a school outside the compound and pay for the additional transport costs, but they may not be able to get into the school because it is too competitive or the fees may be too high.

In all of the compounds more boys than girls attended school and they tended to stay in school longer than the girls. Some girls mentioned that they do not want to go to school because they have no shoes, notebooks, bags or money for school fees. Some said they preferred to have boyfriends instead of going to school. The adolescents agreed that it was those who have money and have parents who work that go to school. When the adolescents were asked why there were more boys than girls in school, they all felt that it was because girls "misbehave" and get pregnant while they are still in school and are forced to drop out. They also said that some parents would rather that the girls work around the home or sell goods at the market than continue their education. The average number of years in school was lower for both boys and girls in Ngombe and Misisi than in the other two compounds.

\section{Sexual activity}

In this study of 10-19 year-olds an adolescent was classified as sexually active if they had intercourse at least once in their lives prior to the study. The definition of a "sexual experience", as understood by the adolescents, was established through body mapping exercises and the evolution of discussions and PLA activities that followed. Many different groups of adolescents were asked to draw the male and female body, label it, and describe the functions of the reproductive system. An example of such a body map is shown in figure 1. In this way it became very clear what the adolescents referred to as "sex" and the researcher was certain that the questions on sexual activity were understood correctly. 
Figure 1: An example of a body map drawn by a group of girls in the Ngombe Compound PLA

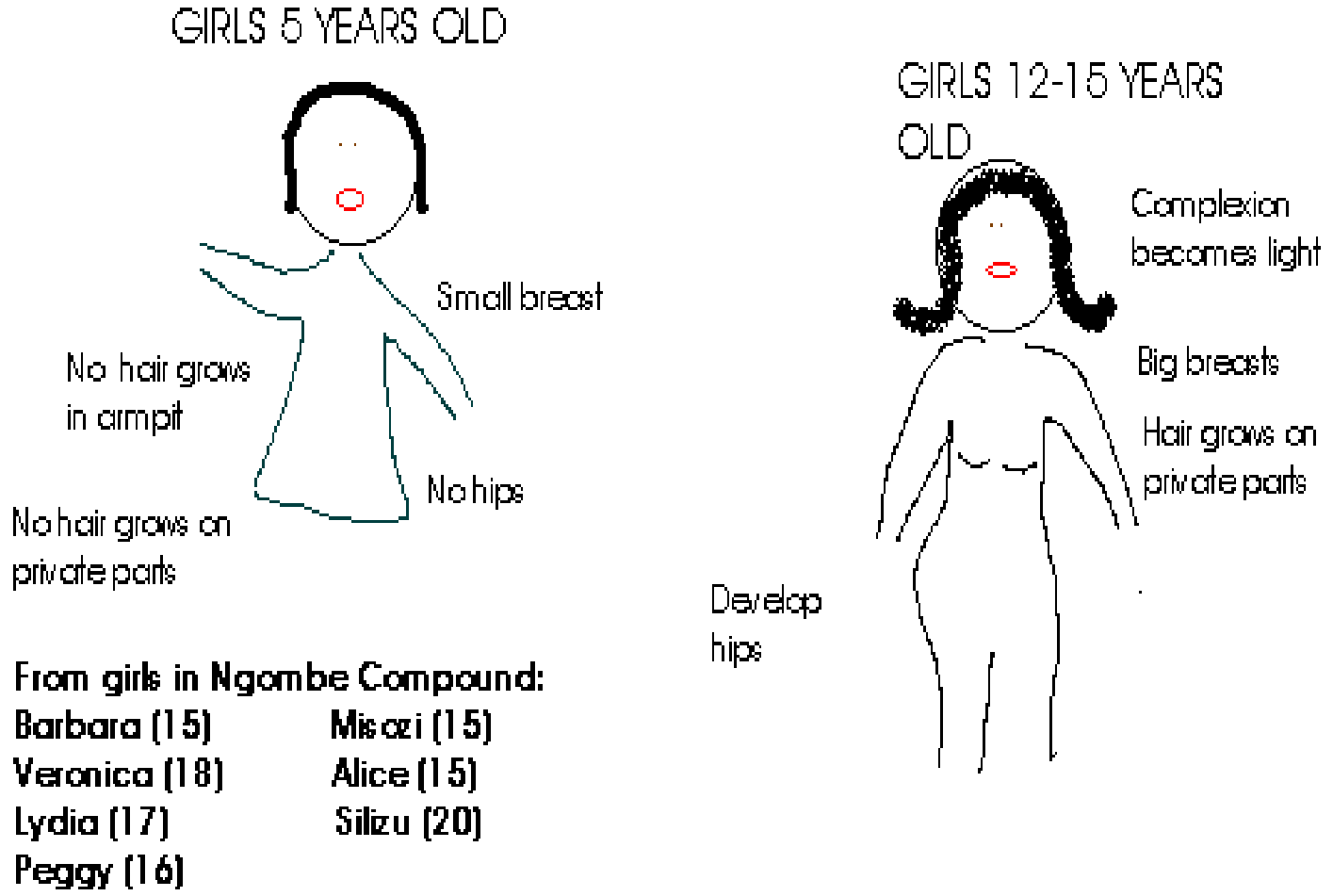

Table 4 shows the proportion of 10-19 year olds surveyed who reported ever having had a sexual experience.

Table 4: $\quad$ Sexual activity among adolescents

\begin{tabular}{|c|c|c|c|c|c|c|c|c|c|c|}
\cline { 2 - 9 } \multicolumn{1}{c|}{} & \multicolumn{2}{c|}{ M'tendere } & \multicolumn{2}{c|}{ New Kanyama } & \multicolumn{2}{c|}{ Misisi } & \multicolumn{2}{c|}{ Ngombe } & \multicolumn{2}{c|}{ TOTAL } \\
\cline { 2 - 10 } & $\begin{array}{c}\mathbf{M} \\
\mathbf{n = 2 0 8}\end{array}$ & $\begin{array}{c}\mathbf{F} \\
\mathbf{n = 1 9 1}\end{array}$ & $\begin{array}{c}\mathbf{M} \\
\mathbf{n = 2 1 4}\end{array}$ & $\begin{array}{c}\mathbf{F} \\
\mathbf{n = 2 0 1}\end{array}$ & $\begin{array}{c}\mathbf{M} \\
\mathbf{n = 2 2 5}\end{array}$ & $\begin{array}{c}\mathbf{F} \\
\mathbf{n = 1 9 2}\end{array}$ & $\begin{array}{c}\mathbf{M} \\
\mathbf{n}=\mathbf{2 0 8}\end{array}$ & $\begin{array}{c}\mathbf{F} \\
\mathbf{n = 1 9 5}\end{array}$ & $\begin{array}{c}\mathbf{M} \\
\mathbf{n}=\mathbf{8 5 5}\end{array}$ & $\begin{array}{c}\mathbf{F} \\
\mathbf{n = 7 7 9}\end{array}$ \\
\hline $\begin{array}{c}\text { Percentage } \\
\text { of } \\
\text { adolescents } \\
\text { who } \\
\text { reported } \\
\text { having } \\
\text { intercourse }\end{array}$ & 68 & 41 & 79 & 56 & 84 & 72 & 76 & 56 & 78 & 56 \\
\hline
\end{tabular}

Figure 2 shows the total number of adolescents surveyed who reported ever having had sexual intercourse, by age. Not surprisingly, the proportion increases among older adolescents. However, what is striking is the high proportion of adolescents who have had sexual intercourse at very young ages. For example, 30 percent of 12 year olds and 41 percent of 13 year olds reported having had sex. 
Figure 2: The proportion of adolescents surveyed who reported ever having had intercourse

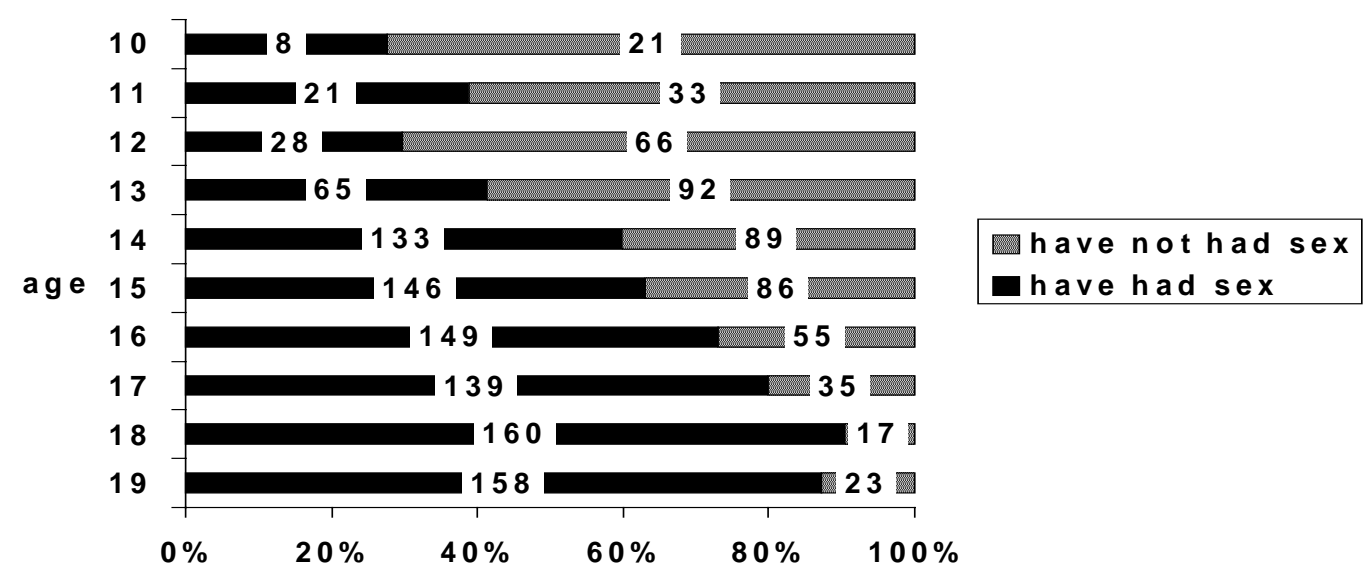

We like those [girls] with breasts because it is enjoyable to play with them. Unfortunately we don't have time to play with the breasts because sex has to be done very fast before we are caught.

Michael, 7 years old

Throughout the PLA exercise we used a variety of techniques to solicit information on age of sexual initiation. On some occasions it was necessary to use a secret "census" for sensitive issues while other groups were very open and casual discussing their experiences. It was interesting to note that girls and boys seemed to estimate the average age of sexual initiation in their community earlier than they reported for themselves. Their own estimates of the average age of sexual initiation almost always fell between the ages of 9 and 12 for both boys and girls. The survey data shows adolescents reporting their own sexual activity beginning slightly later, between 11 and 14 years.

\section{Table 5: $\quad$ Average age at first sex}

\begin{tabular}{|l|c|c|c|c|c|c|c|c|c|c|}
\cline { 2 - 10 } \multicolumn{1}{c|}{} & \multicolumn{2}{c|}{ M'tendere } & \multicolumn{2}{c|}{ New Kanyama } & \multicolumn{2}{c|}{ Misisi } & \multicolumn{2}{c|}{ Ngombe } & \multicolumn{2}{c|}{ TOTAL } \\
\cline { 2 - 10 } \multicolumn{1}{c|}{} & $\mathbf{M}$ & $\mathbf{F}$ & $\mathbf{M}$ & $\mathbf{F}$ & $\mathbf{M}$ & $\mathbf{F}$ & $\mathbf{M}$ & $\mathbf{F}$ & $\mathbf{M}$ & F \\
\hline $\begin{array}{l}\text { Average age at first } \\
\text { sex (years) }\end{array}$ & 11.8 & 13.9 & 11.3 & 13.4 & 12.1 & 13.2 & 12.2 & 12.7 & 11.8 & 13.3 \\
\hline
\end{tabular}

On the whole it can be said that sexual activity starts early among the adolescents in the compound. According to the survey data, about 17 percent of the boys and girls initiate sex before the age of ten. By about the age of 14, more than half the girls and boys are likely to have initiated sex. Girls are likely to have more sexual partners and have sex more frequently just before they reach puberty, followed by a decrease until they are 15-16 years old, when the level of sexual activity peaks among this age group for both sexes. The adolescents felt that younger girls, those who have not reached puberty, tend to feel more free about having sex. As the girl matures, she is afraid of pregnancy and the level of sexual activity decreases. Older boys mentioned similar changes, they felt that as the boy grows older he tends to become more careful about causing a pregnancy and about contracting an STI. 
Also, according to the quantitative data, the boys initiated sex earlier than the girls. This is contradictory to the adolescents' own view that girls, especially out of school girls, mature earlier, drop out of school earlier and therefore initiate sex earlier than the boys. During the PLAs, the adolescents gave a number of reasons supporting this perception, namely, that girls in school fear having to quit school, they are usually taught the dangers of sex in classes and girls in school are more occupied than those out of school. Out of school girls were thought to start having sex earlier than all other groups because they need money, they want relationships, they have more free time, and they often exhibit "bad behavior". Contrary to the belief that girls start sexual activity earlier, data from the adolescents interviewed in the survey concluded that the average age of first sex is slightly younger for boys than girls.

We collected information about the level of sexual activity among these adolescents both from their own individual experiences and their perceptions of their environments. Girls we spoke with said that some boys have several sex partners in a day. They claim that, "they ask for sex even if they don't know you". Some boys buy roots bought from market stalls to enhance their sexual prowess or buy "kill me quick pills" that put girls in a stupor and allow them to seduce them.

Using fixed scores out of 100 the analysis by girls in table 5 gives their own estimates of the proportion of boys and girls in the age group 14-16 years who they think are sexually active. This table shows that they feel a higher proportion of boys in the age group 14-16 years attend school (70 percent of boys as compared to 40 percent girls).

In their opinion, about $50 \%$ of the girls and $71 \%$ of the boys in school are estimated to be sexually active. Among the non-school going, about two-thirds of girls and onethird of boys are estimated to be sexually active. About 35 percent of the sexually active girls (both in and out of school) are likely to become pregnant at this age. More than two-thirds of the girls who become pregnant would try to abort their pregnancy during these years.

Table 6: $\quad$ PLA analysis by a group of 21 grade 7 girls in M'tendere on sexual activity and pregnancy

\begin{tabular}{|c|c|c|c|c|c|c|}
\cline { 2 - 7 } \multicolumn{1}{c|}{} & \multicolumn{4}{c|}{ GIRLS (14 - 16 years) } & \multicolumn{2}{c|}{ BOYS (14 - 16 years) } \\
\cline { 2 - 7 } \multicolumn{1}{c|}{} & $\begin{array}{c}\text { Proportion } \\
\text { (distribution) }\end{array}$ & $\begin{array}{c}\text { Sexually } \\
\text { active }\end{array}$ & Pregnant & $\begin{array}{c}\text { Abort } \\
\text { pregnancy }\end{array}$ & $\begin{array}{c}\text { Proportion } \\
\text { (distribution) }\end{array}$ & $\begin{array}{c}\text { Sexually } \\
\text { active }\end{array}$ \\
\hline In school & 40 & 20 & 7 & 5 & 70 & 50 \\
\hline $\begin{array}{c}\text { Out of } \\
\text { school }\end{array}$ & 60 & 40 & 15 & 10 & 30 & 10 \\
\hline Total & 100 & 60 & 22 & 15 & 100 & 60 \\
\hline
\end{tabular}

A group of school girls in M'tendere Compound provided information on the number of times they have had sex in the last three months. This question was asked especially to understand the level of sexual activity among this age group, and was in a sequence of questions to which the group members responded by writing their replies on a small piece of paper. Responses from a group of thirty-nine grade seven girls in the age group 13-16 show that one-third of the girls were sexually active in the last three months. While six girls had sex only once during the last three months, one 
girl had sex 10 times. Most of the girls had sex three or less times during the last three months. Twenty girls in this group had indicated earlier that they have had sex with a boy at least once so far, implying that 65 percent of the girls who had initiated sex were actually sexually active during the last three months. Some girls explained that not all girls continued to have regular sex because their curiosity about the act of sex is satisfied the first time. Some also mentioned that they did not like the first experience and hence put off the second one.

The same analysis was carried out in M'tendere with 26 grade seven boys, in the age group 13-15 years. Almost 40 percent (10/16) of these boys had been sexually active during the last three months. Most of them had sex once or two times during this period. We asked why some "sexually active boys did not have sex in the recent past", the reasons they gave were similar to the girls' responses although some boys also mentioned that sometimes they do not have the money to pay the girls for sexual favors. 5 The same groups of grade seven boys from M'tendere also wrote down on slips of paper, the number of sex partners they have had in their lifetime. The responses are shown in table 6.

Table 7: $\quad$ Results of a secret sex census on number of sex partners to date from a group of 26 grade 7 boys from M'tendere

\begin{tabular}{|c|c|}
\hline Number of partners & Number of boys \\
\hline 0 & 6 \\
\hline 1 & 3 \\
\hline 2 & 3 \\
\hline 3 & 6 \\
\hline 4 & 1 \\
\hline 5 & 2 \\
\hline 6 & 2 \\
\hline 7 & 2 \\
\hline 8 & 1 \\
\hline
\end{tabular}

This means that of the twenty boys who have experienced sex so far, 40 percent have had four or more sex partners to date; one boy had already had eight sexual partners. In a similar analysis of ten slightly older adolescents from Misisi Compound, the number of lifetime partners varied from two to twelve.

The following table shows a similar analysis of in and out of school girls and boys from Ngombe Compound and their sexual partners over the past three months.

$5 \quad$ This kind of an analysis where the boys and girls were able to answer questions individually without having to reveal their identity or letting others know their response was very helpful in generating information on sensitive topics. Both of these groups, the boys and girls, were larger than what is conducive for such discussion. 
Table 8: Results of an exercise with a mixed group of boys and girls both in and out of school from Ngombe Compound

Responses from four girls (14 - 20 years)

Responses from five boys (14 - 20 years)

\begin{tabular}{|c|c||c|c|}
\hline $\begin{array}{c}\text { No. of sexual partners } \\
\text { in past three months }\end{array}$ & $\begin{array}{c}\text { No. of sex acts in the } \\
\text { past three months }\end{array}$ & $\begin{array}{c}\text { No. of sexual partners } \\
\text { in past three months }\end{array}$ & $\begin{array}{c}\text { No. of sex acts in the } \\
\text { past three months }\end{array}$ \\
\hline 2 & 8 & 6 & 13 \\
\hline 2 & 8 & 5 & 10 \\
\hline 1 & 2 & 4 & 8 \\
\hline 1 & 1 & 4 & 6 \\
\hline & & 2 & 4 \\
\hline
\end{tabular}

Both young boys and girls are commonly initiating sex before grade 7 (13 years of age) and changing sexual partners frequently. While knowledge of modes of transmission of HIV and STIs is high among these adolescents and awareness of the condom for protection is almost universal, in compounds where an estimated 28 percent of adults are infected with $\mathrm{HIV}^{6}$, high levels of sexual activity and multiple sex partners continue to put young peoples' lives at risk.

Table 9 illustrates the proportion of adolescents surveyed who have had sex with multiple sex partners in the past three months.

Table 9: $\quad$ Frequency of sexual intercourse

\begin{tabular}{|c|c|c|c|c|c|c|c|c|c|c|}
\hline & \multicolumn{2}{|c|}{ M'tendere } & \multicolumn{2}{|c|}{ New Kanyama } & \multicolumn{2}{|c|}{ Misisi } & \multicolumn{2}{|c|}{ Ngombe } & \multicolumn{2}{|c|}{ TOTAL } \\
\hline & $\begin{array}{c}M \\
n=142\end{array}$ & $\begin{array}{c}F \\
n=80\end{array}$ & $\begin{array}{c}M \\
n=168\end{array}$ & $\begin{array}{c}F \\
n=113\end{array}$ & $\begin{array}{c}M \\
n=189 \\
\end{array}$ & $\begin{array}{c}\mathrm{F} \\
\mathrm{n}=138\end{array}$ & $\begin{array}{c}M \\
\mathbf{n}=157\end{array}$ & $\begin{array}{c}\mathbf{F} \\
n=109\end{array}$ & $\begin{array}{c}M \\
n=656\end{array}$ & $\begin{array}{c}\mathrm{F} \\
n=440\end{array}$ \\
\hline $\begin{array}{l}\text { Percentage of } \\
\text { sexually active } \\
\text { adolescents who have } \\
\text { had sex at least once } \\
\text { in last } 3 \text { months }\end{array}$ & 43 & 31 & 51 & 65 & 71 & 58 & 54 & 44 & 54.8 & 49.5 \\
\hline $\begin{array}{l}\text { Percentage of } \\
\text { sexually active } \\
\text { adolescents who have } \\
\text { had more than one } \\
\text { sex partner in last } 3 \\
\text { months }\end{array}$ & $\begin{array}{c}(\mathrm{n}=61) \\
54\end{array}$ & $\begin{array}{c}(\mathrm{n}=25) \\
28\end{array}$ & $\begin{array}{c}(\mathrm{n}=86) \\
57\end{array}$ & $\begin{array}{c}(\mathrm{n}=73) \\
18\end{array}$ & $(n=134)$ & $(\mathrm{n}=80)$ & $(\mathrm{n}=95)$ & $(n=51)$ & $\begin{array}{c}(\mathrm{n}=376) \\
55\end{array}$ & $\begin{array}{c}(n=229) \\
39.5\end{array}$ \\
\hline
\end{tabular}

The following analysis, from a PLA, illustrates the common perception (from a group of boys) that school acts as a deterrent to sexual activity in boys and girls:

Table 10: $\quad$ Estimated sexual activity of Misisi adolescent girls based on school attendance prepared by fifteen 12-19 year-old boys

\begin{tabular}{|c|c|c|c|}
\hline 200 BOYS & \multicolumn{3}{|c|}{200 GIRLS } \\
\hline $\begin{array}{c}\text { In school and sexually } \\
\text { active } \\
50 / 100\end{array}$ & $\begin{array}{c}\text { Out of school and } \\
\text { sexually active } \\
100 / 100\end{array}$ & $\begin{array}{c}\text { In school and } \\
\text { sexually active } \\
70 / 100\end{array}$ & $\begin{array}{c}\text { Out of school and } \\
\text { sexually active } \\
100 / 100 \text { active }\end{array}$ \\
\hline
\end{tabular}

$6 \quad$ HIV/AIDS in Zambia, MOH/CBOH, December, 1997 
The same pattern occurred with a group of New Kanyama adolescents given a hypothetical number of fifty adolescents in, and fifty out of school. The purpose was to explore how adolescents feel that sexual activity relates to school attendance. Their response was that $45 / 50$ of those out of school would be sexually active and only $25 / 50$ of the in school adolescents would be sexually active. This information again shows that the adolescents believe that the out of school adolescents are more sexually active than those in school.

Several groups of girls did not feel that the level of sexual activity between in and out of school girls would be any different. One group of 12-17 year-olds (in and out of school) even suggested that sexual activity amongst out of school girls would be 30 percent lower than sexual activity among a similar age group of girls in school. When we explored this disparity with them they explained that in school girls face a lot of peer pressure from their friends. Some girls would exchange sex for answers to tests or homework. Many of these girls also need two boyfriends, one to buy them snacks at school and another to give them money outside of school; they felt that girls out of school had fewer needs.

Our attempt to establish a definitive association between school attendance and age at first sex was not very successful because the survey questionnaire did not specifically ask whether the respondent was in school at the time of their first sexual experience. Thus it is almost impossible to know for sure whether the sexually active out-ofschool adolescents were already out of school when they had their first sex experience. According to the quantitative data, "out of school" means that they were out of school at the time of the interview. However, comparing the average age of first intercourse with the average age of school dropout suggests that even those adolescents who are presently out of school are likely to have had their first sexual experiences while they were still in school. Among adolescents interviewed, the average number of years in school was seven years, and very few adolescents had never been to school (two percent of the total group and less than one percent of these were sexually active). This figure includes adolescents who are no longer in school at the time of the interview (drop outs). In Zambia children normally go to school between the ages of 6 and 7, this means that most of these out of school adolescents started dropping out at age 13 or 14 , which is higher than the average age of sexual initiation for both boys and girls.

\section{Relationship with first sex partner}

According to survey data, friends and neighbors were by far the most common sex partners among these adolescents. 
Table 11: Adolescents' sex partners

\begin{tabular}{|l|c|c|}
\hline $\begin{array}{l}\text { Percentage of sexually active adolescents } \\
\text { whose first sex partner was a : }\end{array}$ & $\begin{array}{c}\text { Male } \\
\mathbf{n = 6 7 5}\end{array}$ & $\begin{array}{c}\text { Female } \\
\mathbf{n = 4 4 7}\end{array}$ \\
\hline Friend & 45 & 60 \\
\hline Neighbor & 38 & 22 \\
\hline Cousin & 5 & 5 \\
\hline Stranger & 5 & 5 \\
\hline Prostitute & 1 & 0 \\
\hline Other & 6 & 8 \\
\hline Total & 100 & 100 \\
\hline
\end{tabular}

In the questionnaire we included the option to choose "stranger" as a first sex partner. This was an attempt to establish a measure for nonconsensual sex which is not openly discussed in Zambia. Overall, five percent of boys and girls indicated that a stranger had been their first sex partner. Males in three compounds reported first sex experiences with prostitutes although the percentages are very low. The following pie chart shows the most common responses regarding first sex partners as reported in surveys from two of the compounds.

\section{Figure 3: $\quad$ Adolescent relations with first sex partner as reported} in survey data in two compounds

\section{Mtendere \\ Male Female}
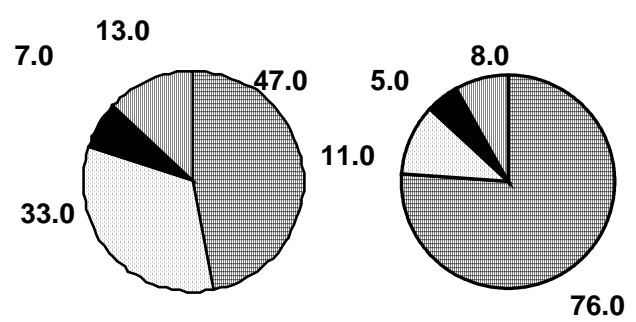

Friend $\square$ Neighbor ${ }_{\text {Cousin }} \square$ Other

\section{New Kanyama Male \\ Female}

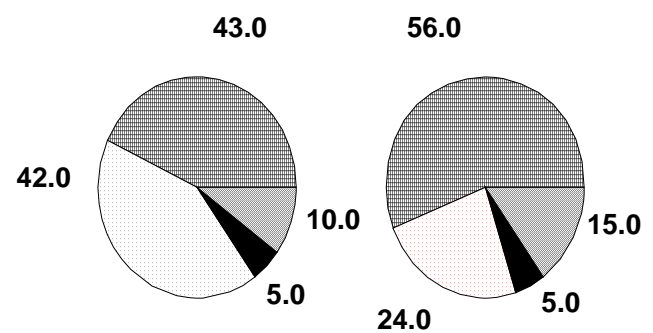

Friend $\square$ Neighbor $\square$ Cousin $\square$ Other

During the PLA exercises neither strangers nor prostitutes came up as common sex partners but remuneration for sexual activity, including first sexual experiences, was still very common.

\section{Living arrangements and sexual activity}

A significant number of exercises during the PLAs addressed the adolescent living arrangements and the likelihood of engaging in early sexual activity, especially for girls. Most of the sexually active adolescents interviewed were living with both parents but many stayed with aunts, uncles, stepparents or grandparents. Their perception was that who an adolescent lives with affects their likelihood of engaging in early sexual activity and becoming pregnant. The following analysis by a group of 
girls from M'tendere Compound gives an example of their beliefs about sexual activity and living arrangements.

Table 12: Living arrangement and pregnancy

\begin{tabular}{llll}
\hline & $\begin{array}{l}\text { Ranking of living } \\
\text { arrangements }\end{array}$ & $\begin{array}{l}\text { Ranking of likelihood of } \\
\text { becoming pregnant by } \\
\text { living arrangement }\end{array}$ & $\begin{array}{l}\text { Free scoring of } \\
\text { proportion of girls likely } \\
\text { to get pregnant }\end{array}$ \\
\hline Mother & 1 & 3 & 20 \\
\hline Both parents & 2 & 5 & 5 \\
\hline Grandmother & 3 & 1 & 94 \\
\hline Uncle & 4 & 4 & 13 \\
\hline Sister & 5 & 3 & 20 \\
\hline Stepmother & 6 & 2 & 41 \\
\hline Ranking: $1=$ most common/likely, 6 = least common/likely &
\end{tabular}

The above analysis shows that most of the adolescents live with their mothers, followed by both parents and that girls living with their grandmothers are most likely to become pregnant, since they are also the most sexually active group. Interestingly, it is grandparents who are listed as a common source of sexual information and as someone to turn to in times of crisis.

\section{Reasons for Sex}

The reasons for sex among the male adolescents and their female counterparts were quite different. For most boys, sex (and desire) is seen as a natural part of growing up. Boys also gave a number of reasons related to peer pressure, proving manhood, love "when you have sex the love gets stronger", or if you don't have a girlfriend your friends laugh at you. For girls in school it was curiosity, help with schoolwork, love, and/or the opportunity to earn pocket money or snacks that determined whether she wanted to have sex with the boy. They also agreed to have sex with teachers for "leakage" of exam papers and other favors from the teachers. Some girls also said that they had sex for pleasure, to prove they were fertile, or to appease their boyfriends who claimed they would leave them.

Through the qualitative research we found that forced sexual activity was quite common, with a few girls' groups drawing Venn diagrams indicating as much as half of adolescent sexual activity being forced. As seems to be the case in many cultures, they indicated that much of this is with people that they know. When the issue of forced sex was discussed with groups of boys and girls, it was explained that the type and level of force varies from threats to beating the girls and, in some cases, knives to threaten the girl if she refuses to have sex with them. While most of the girls enter sexual relationships willingly and voluntarily, it was estimated that about 20 percent of sexual activity is forced.

All of our research indicates that there is a high level of sexual activity among the adolescents in the compound. Of course there are some boys and girls who refrain from sexual activity for various reasons. Most of these boys and girls, it was explained, are "good Christians" and do not want to have sex before marriage or are afraid of contracting STIs like AIDS. Some boys said they had no money to pay for sex or they were afraid of the family's witchcraft should they cause a pregnancy. 
Some girls were afraid of becoming pregnant and being disowned by parents or being at a disadvantage to marry.

\section{Payment for Sex}

\begin{tabular}{|}
$\begin{array}{l}\text { One group of boys told us that "it began in } 1993 \text { when hardships increased, sex for money } \\
\text { increased as did the number of abortions so that girls could continue to make money". } \\
\text { Misisi Compound field notes }\end{array}$ \\
\hline
\end{tabular}

In spite of all of the reasons for sex listed above, the results of the PLA and the survey indicate that most of the sexual activity is associated with some form of gift or payment to the girl. According to the survey findings one-half to two-thirds of the last sex acts reported were remunerated. Usually the boys do the paying while the girls provide the "service". Some boys even said they preferred sex with younger girls because they do not demand a lot of money or expensive presents in return.

Table 13: $\quad$ Payment for sex

\begin{tabular}{|c|c|c|c|c|c|c|c|c|c|c|}
\cline { 2 - 9 } \multicolumn{1}{c|}{} & \multicolumn{2}{c|}{ M'tendere } & \multicolumn{2}{c|}{ New Kanyama } & \multicolumn{2}{c|}{ Misisi } & \multicolumn{2}{c|}{ Ngombe } & \multicolumn{2}{c|}{ TOTAL } \\
\cline { 2 - 9 } & $\begin{array}{c}\mathbf{M} \\
\mathbf{n}=\mathbf{1 4 2}\end{array}$ & $\begin{array}{c}\mathbf{F} \\
\mathbf{n}=\mathbf{8 0}\end{array}$ & $\begin{array}{c}\mathbf{M}=\mathbf{1 6 8} \\
\mathbf{n}\end{array}$ & $\begin{array}{c}\mathbf{F}=\mathbf{1 1 3} \\
\mathbf{n}\end{array}$ & $\begin{array}{c}\mathbf{M} \\
\mathbf{n}=\mathbf{1 8 9}\end{array}$ & $\begin{array}{c}\mathbf{F} \\
\mathbf{n = 1 3 8}\end{array}$ & $\begin{array}{c}\mathbf{M} \\
\mathbf{n = 1 5 7}\end{array}$ & $\begin{array}{c}\mathbf{F} \\
\mathbf{n}=\mathbf{1 0 9}\end{array}$ & $\begin{array}{c}\mathbf{M} \\
\mathbf{n}=\mathbf{6 5 6}\end{array}$ & $\begin{array}{c}\mathbf{F} \\
\mathbf{n = 4 4 0}\end{array}$ \\
\hline $\begin{array}{c}\text { Percentage of } \\
\text { sexually active } \\
\text { adolescents } \\
\text { who received } \\
\text { money/gift for } \\
\text { sex }\end{array}$ & 0 & 66 & 4 & 53 & 1 & 69 & 1 & 70 & 1.5 & 64.5 \\
\hline $\begin{array}{c}\text { Percentage of } \\
\text { sexually active } \\
\text { adolescents } \\
\text { who gave } \\
\text { money/gift for } \\
\text { sex }\end{array}$ & 40 & 0 & 7 & 0 & 57 & 0 & 35 & 0 & 34.8 & 0 \\
\hline
\end{tabular}

A group of 12-17 year-old girls in Misisi created a list of potential sex partners and the expected payments shown below. 
Table 14: Potential sex partners and corresponding payments from a group of 12 - 17 year-old girls

\begin{tabular}{|ll|}
\hline \multicolumn{1}{|c|}{ Boyfriend } & \multicolumn{1}{c|}{ Expected Payment } \\
Kawalala (thief) & Kw 10,000 \\
Kantemba (vendors) & Lotion, soap, biscuits, sweets \\
Unemployed (for love) & Kw 2,000 \\
Hule (prostitute) & Kw 70,000 \\
Teacher & Past papers \\
Schoolboys & Answers to homework or tests \\
Footballers & Kw 5,000 \\
\hline
\end{tabular}

Exchange (remuneration) for sex and partnership is deeply embedded in the culture of these adolescents and certainly not thought of as prostitution. Usually boys give voluntarily and girls consent to most sex acts but the exchange, usually benefiting the girl, seems embedded in the culture because of the inherent power and economic disadvantage of girls. The following stories of three sexually active 11-14 year-old boys from M'tendere narrate their sexual encounters and the gifts tied to them:

One 13 year-old had sex with two girls; to the first one he gave a pencil and she agreed to have sex in return. To the second one he proposed while playing hide and seek and she agreed. He gave the first one K500 and the second bananas and sweets after having sex with them. He mentioned that one of the girls had given him bubble gum and the second nyama nyama ('skin to skin' sexual intercourse) as 'gifts'.

One 11 year- old had sex with two girls; he wrote a letter to the first girl and she refused to have sex with him. He said "I love you" to the second one and she agreed but they have not had sex. He has given the girl K500 and popcorn and has received popcorn and an apple from her.

One 12 year-old boy has had sex with three girls; he gave the first girl a pen, but she refused to have sex with him. He proposed to the second girl while playing hide and seek and she also refused. To the third girl he proposed with a gift of a banana and she agreed to have sex with him. He gave her K100, popcorn, sweets, an apricot and a mango. She gave him some spaghetti.

Extract from the field notes of Jericho Chambilwa and Chrispin Simbotwe

In all of the compounds, adolescents maintained during the PLA research that condom use was a deciding factor in payment for sex. In-school girls were said to receive 5001500 Kwacha (US\$ 0.40 - 1.50) for a sex act while out-of-school girls charge according to the status of the man or according to condom use or not, out-of-school girls could "charge" as much as 10,000 Kwacha per hour depending upon the meeting place. In Misisi Compound it was reported that, "Some girls want to use condoms so that they don't get sick with AIDS or Bola-bola but other girls prefer not to use them so that they can get more money from the boys. Girls who insist on using condoms get paid between K30,000 - 45,000 but girls who go without can sometimes make more than Kw 50,000 - Kw 60,000." In all of the compounds we heard that some girls are sent by their guardians to engage in sexual activity for money or food but this 
was never confirmed by any young girls themselves. The following comment from M'tendere field notes shows the indirect way girls are encouraged to exchange sex for money.

Several groups of boys and girls narrated instances when a mother or grandmother would ask the girl to seek sex partners so that there is some money at home and they can have enough food to eat. However, it was mentioned that the girl would not be told directly to go and have sex but a mother could pass comments like "sure ti gona nanjala na bakazi balipo pano" (Surely how can we sleep on empty stomachs when there are girls in the house)?

Extract from the field notes of Thomas Moyo, M'tendere Compound

During the PLA we solicited information on preferences in sexual partners. The lists were long and included a variety of categories ranging from close relatives to thieves, gangsters, and drivers. The following analysis was carried out by a group of out-ofschool girls from M'tendere.

\section{Table 15: $\quad$ PLA typology of common sex partners for girls}

\begin{tabular}{lcc}
\hline \multicolumn{1}{c}{ Type of male partners } & $\begin{array}{c}\text { Reasons and amount paid to the } \\
\text { girl }\end{array}$ & $\begin{array}{c}\text { Free score showing how } \\
\text { common the relationship* }\end{array}$ \\
\hline Kawalala (thief) & $\begin{array}{c}\text { K 100,000 } \\
\text { They have a lot of money }\end{array}$ & 107 \\
\hline $\begin{array}{l}\text { Truck, mini-bus and taxi } \\
\text { drivers }\end{array}$ & $\begin{array}{c}\text { K 50,000 - 60,000 } \\
\text { They have a lot of money } \\
\text { Give free rides }\end{array}$ & 63 \\
\hline Gonena (bus conductors) & $\begin{array}{c}\text { K1,000 upwards } \\
\text { For free rides }\end{array}$ & 43 \\
\hline Kaponya (vendors) & $\begin{array}{c}\text { Gives items from his } \text { ntemba free } \\
\text { Can have sex in the stalls at night }\end{array}$ & 24 \\
\hline Sugar Daddies & $\begin{array}{c}\text { K20,000 -K 50,000 } \\
\text { Includes married men }\end{array}$ & 20 \\
\hline Business men & K5,000-K10,000 & 16 \\
\hline $\begin{array}{l}\text { Teacher } \\
\text { for girls in school) }\end{array}$ & $\begin{array}{c}\text { For answer sheets, security that the } \\
\text { teacher will not beat us in class and } \\
\text { other favors }\end{array}$ \\
\hline $\begin{array}{l}\text { Classmates } \\
\text { for girls in school) }\end{array}$ & $\begin{array}{c}\text { K50-K100 } \\
\text { For sweets, toys, drinks }\end{array}$ \\
the higher the score the more sought after the relationship \\
\hline
\end{tabular}

\section{Adolescent sources of information}

The adolescents interviewed in these compounds revealed limited knowledge about the reproductive system, STIs and modern contraceptive methods. Most of the knowledge they possess seems to be acquired through three major sources: verbal information from friends and grandparents, the media, and practical experience. Surprisingly, a lot of what they know seems to be coming down from their grandparents. Most of them feel that they can speak more freely about sexual matters with their grandparents than anyone else, least of all their parents. They are afraid to 
admit any knowledge of sex and related matters, let alone their experiences, to their parents for fear of being asked how they know about such things. Such an inquisition could end up in a nasty beating and probably stern 'economic and social sanctions' against the adolescent as a punishment for knowing things he/she is not supposed to know. Adolescents also speak with aunts, friends, elder siblings, local health centers and churches for information about sexual relations. The graph below shows the results from the M'tendere survey data when youth were asked "to whom do you discuss issues related to sexuality?"

\section{Results of survey data from M'tendere adolescent sources of information on sexual health}

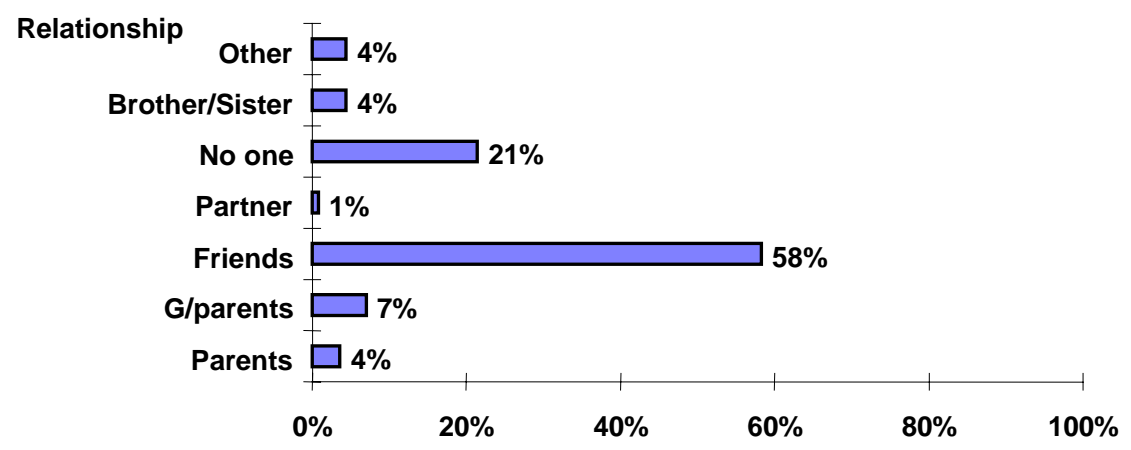

Radio, movies and television also came out as important sources of information. Since most of the adolescents interviewed identify themselves as either the poor or middle class in the wealth ranking, their access to media at home is limited. They go to video clubs, where they pay a fee of K50-K100 (US\$.08) to watch movies. A wide variety of movies are shown in these video clubs but most of them are some type of sex or action movies.

The sexual activity of some domestic animals, especially dogs and chickens, was given as another source of information about sex and a reason for arousal. The sexual behavior of adults is another source of information for adolescents. Because of the crowded living conditions in these compounds teens often see adults having sex in public places at night or having sex in unfinished buildings, they peep through the uncovered windows to watch adults and then become tempted to go out and copy the sexual behavior. Finally, traditional healers, ngangas, also came out as an important source of information about STIs and their treatment. Since many of the adolescents interviewed stopped school early, the school did not feature as an important source of information about sexual health. However, continued school attendance (especially for girls) and earlier education regarding sexuality and sexual education were believed to be a deterrent to early sexual activity. 


\section{Pregnancy Prevention}

Quantitative findings suggest that 30-40 percent of sexually active males and 20-30 percent of sexually active female adolescents have used a condom at least once.

Table 16: Use of condoms and other contraception

\begin{tabular}{|l|c|c|c|c|c|c|c|c|c|c|}
\cline { 2 - 10 } \multicolumn{1}{c|}{} & \multicolumn{2}{c|}{ M'tendere } & \multicolumn{2}{c|}{ New Kanyama } & \multicolumn{2}{c|}{ Misisi } & \multicolumn{2}{c|}{ Ngombe } & \multicolumn{2}{c|}{ TOTAL } \\
\cline { 2 - 10 } & $\begin{array}{c}\mathbf{M} \\
\mathbf{n}=\mathbf{1 4 2}\end{array}$ & $\begin{array}{c}\mathbf{F} \\
\mathbf{n}=\mathbf{8 0}\end{array}$ & $\begin{array}{c}\mathbf{M} \\
\mathbf{n}=\mathbf{1 6 8}\end{array}$ & $\begin{array}{c}\mathbf{F} \\
\mathbf{n}=\mathbf{1 1 3}\end{array}$ & $\begin{array}{c}\mathbf{M} \\
\mathbf{n = 1 8 9}\end{array}$ & $\begin{array}{c}\mathbf{F} \\
\mathbf{n}=\mathbf{1 3 8}\end{array}$ & $\begin{array}{c}\mathbf{M} \\
\mathbf{n}=\mathbf{1 5 7}\end{array}$ & $\begin{array}{c}\mathbf{F} \\
\mathbf{n = 1 0 9}\end{array}$ & $\begin{array}{c}\mathbf{M} \\
\mathbf{n}=\mathbf{6 5 6}\end{array}$ & $\begin{array}{c}\mathbf{F} \\
\mathbf{n}=\mathbf{4 4 0}\end{array}$ \\
\hline $\begin{array}{l}\text { Percentage of sexually active } \\
\text { adolescents who have used a } \\
\text { condom at least once. }\end{array}$ & 32 & 21 & 30 & 27 & 40 & 24 & 33 & 26 & 33.7 & 24.5 \\
\hline $\begin{array}{l}\text { Percentage of sexually active } \\
\text { adolescents who have used } \\
\text { 'contraception' at least once }\end{array}$ & 13 & 16 & 26 & 25 & 11 & 20 & 26 & 26 & 19 & 21.8 \\
\hline
\end{tabular}

The qualitative data suggest a general mistrust of condoms among adolescents. During discussions and secret censuses with adolescents in the field they rarely reported condom use during sex and most regarded it as an inappropriate method for young people ("it's too big) and an ineffective method ("it can burst" or "boys prick it to get back at you"). In a group of 12-15 year-old schoolboys from M'tendere, twelve said that they had used condoms sometimes but none of them used them regularly. Many girls, and even one boy, said that they used a condom on the first date but quickly stopped using them under protests of lack of trust or love for one's partner. The stigma surrounding girls negotiating condom use or carrying condoms is very pervasive in these areas. Some groups of boys just laughed at the idea that a girl would negotiate using a condom and many girls felt that boys would get back at them by tearing holes in the condoms the next time. The majority of these protected sexual acts may have been negotiated by boys in late adolescence. The graph below illustrates the age distribution of girls and boys having used condoms at least once in the four compounds (based on survey data).

\section{Figure 5: Age of adolescents reporting condom use}

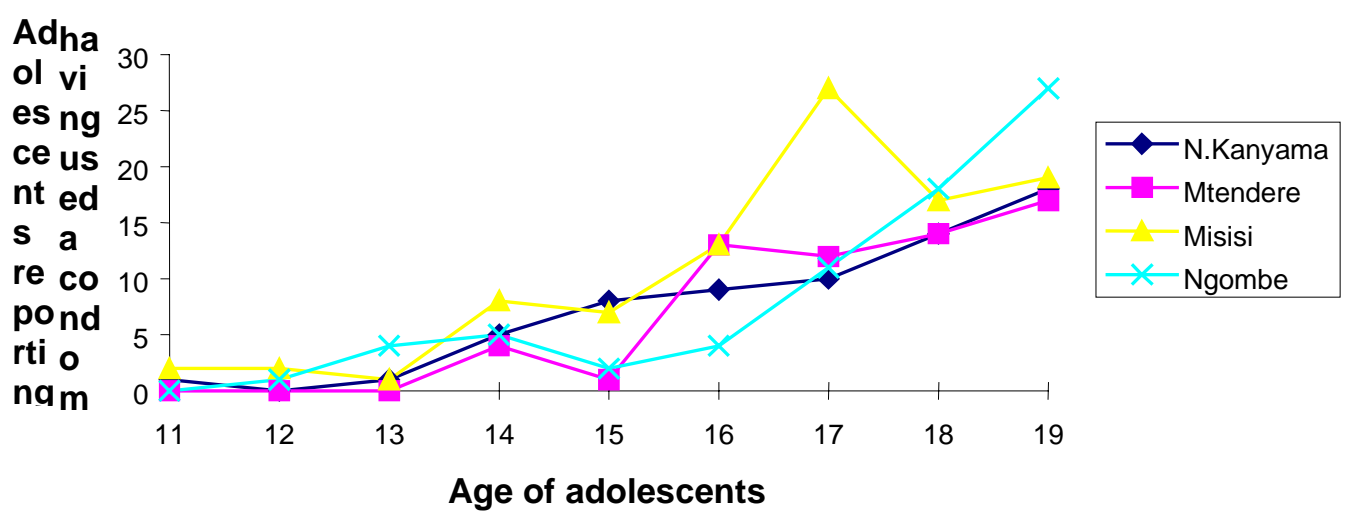

Many of the adolescents said that they disliked using condoms during sex. One boy provoked laughter when he said that condoms are "Ah mudala tiziba matenda yaliko 
maje vima condom neve feki!" (It is like eating meat in a plastic). Some adolescents felt that young boys under 14 years old are not mature or their "sperms are not strong enough" to impregnate a girl. The frequency of condom use varied with the age of the adolescents. Most of the young people said that it would be very rare if a boy or girl used a condom before they were 15 years old and the thought that a 12 year-old girl would use a condom provoked laughter from a group of girls. This may reflect the younger adolescents' beliefs that they are too young to become or make someone pregnant and that young people don't have to worry about STIs. Condom use among boys starts at age fifteen because they "feel the danger of making a girl pregnant" and increases at age seventeen "because they want to be careful" (protected from STIs). The use of condoms decreases at the age of eighteen and further still at nineteen because the level of their sexual activity decreases and more boys start sticking to one partner.

All of these adolescents said that it was very unusual for a girl to ask a boy to use a condom and if she did she would be considered to be "sick" (with AIDS or an STI) and the girls were afraid that they would be called a hule (prostitute). Some boys and girls believed that as long as their partners looked beautiful and healthy there was no need to have protected sex. One group of boys felt that boys only need to use condoms with "sophisticated girls" and that you know these girls by their looks. Some adolescents believed that continual use of condoms was harmful as it could lead to impotence of the user. Condoms were felt to be a method for protection from disease and not for preventing pregnancy. However, in all of the compounds condoms were seen as an inadequate method of disease prevention because they were thought to be ineffective and a method that could not be negotiated by girls. They asked, Unga kwanise ma condom lonse? ("Can one really manage using condoms every time?") and said that "skin to skin" sex feels better. It was a common perception that condoms in Zambia are too big for young boys. Some girls were afraid that condoms would fall off and remain in their "womb". Many teens also felt that abstinence was the only sure way to prevent pregnancy because condoms "can burst" or allow HIV viral particles to pass through.

A group of 21 boys from M'tendere, aged 9-20 years, mentioned that some school girls and pretty girls usually suggest the use of a condom during sexual intercourse. In such a case the boy would wear a condom but tear off the tip of the condom just before inserting his penis in the girl's vagina, without the girl being aware of the boy's action. The boys felt that these girls were very proud of themselves and therefore tearing off the condom was meant as a punishment, with a hope that she becomes pregnant and at the same time confused about who fathered the child.

Extract from the field notes of Thomas Moyo

In all of our data the figures for contraceptive use were even lower than those for condom use. Most often, when we spoke of "family planning" or "contraception", the adolescents did not identify condoms as a method. This is most likely, in part, the result of a strong condom social marketing project, which primarily promotes condoms for disease prevention. While nearly one quarter of girls and boys said they 
had used a method to prevent pregnancy at least once, very few said they always used a method.

Adolescents have some knowledge of both traditional and modern contraceptive methods although their discussions erupted into many debates about the mechanism of these methods. It is impossible to know how reliable some of the traditional family planning methods actually are but the awareness of them and belief in their efficacy is high. Some methods are believed to serve as abortifacients, while others actually prevent pregnancy, but the difference was often a point of contention between these adolescents. Some girls felt that the quantity or timing or the application of traditional methods was the only difference between preventing pregnancy and inducing an abortion; arguments arose in some of the groups about whether drugs or herbs should be taken before or after intercourse, and an agreement could not be reached. Some girls insisted that herbs and capsules are effective if taken before having sex and others said that you must take it after intercourse to weaken the sperms.

The adolescents were able to name the following modern and traditional family planning methods and abortifacients, as shown in table 17.

Table 17: Family Planning method mentioned by groups of adolescent boys and girls in Misisi Compound

\begin{tabular}{|c|c|c|}
\hline $\begin{array}{l}\text { Method } \\
\quad \quad \text { Condoms }\end{array}$ & Use & Availability \\
\hline - $\quad$ Abstinence & & \\
\hline - Withdrawal & During childhood sex & $\begin{array}{l}\text { Common practice in Christian } \\
\text { families }\end{array}$ \\
\hline Kachasu (local home brew) & Drink before sex & Common in the compound \\
\hline - $\quad$ Family planning pills & Take before sex & Clinic, chemist, shops, hospital \\
\hline - Muleza root & $\begin{array}{l}\text { Soak roots and drink the tea } \\
\text { soon before or after sex }\end{array}$ & $\begin{array}{l}\text { Herbalists, markets, friends, } \\
\text { elders }\end{array}$ \\
\hline - $\quad$ Red and black capsules & Take soon before or after sex & Market, street vendors, shops \\
\hline - Kankalamba root & $\begin{array}{l}\text { Soak roots and drink the tea } \\
\text { soon before or after sex }\end{array}$ & $\begin{array}{l}\text { Herbalists, markets, friends, } \\
\text { elders }\end{array}$ \\
\hline - Injections & $\begin{array}{l}\text { Inject medicine into the blood } \\
\text { through the arm }\end{array}$ & Clinic, hospital \\
\hline
\end{tabular}

Most girls preferred to use locally bought contraceptives rather than the free contraceptives supplied at the health center. These include either socially marketed modern methods from the pharmacy or special "family planning capsules" or traditional drinks bought at the market. Chileza, herbs and beads tied around the waist for protection from pregnancy, was a commonly mentioned method. Many girls, especially the older ones, used charms and traditional drinks as contraceptives saying that these can be used secretly so that they are "able to have control over their use". Some young girls believed that using modern contraception at an early age could lead to infertility. Some adolescents spoke of injections at the clinic that could protect you from pregnancy for up to one year or tablets bought on the streets and inserted in the 
vagina that could also protect you from pregnancy for a year. One group of girls said that for contraception they avoid talking to boys when the girl is about to menstruate (the girls said that they feel very sexy during this time).

These young people also preferred going to ngangas (traditional healers) for contraception. They felt that ngangas were more capable of keeping secrets and never run out of medicines as they do in the clinics. The ngangas are not concerned with age nor do they ask why you want to use contraception. "The other advantage of the nganga is that he does not undress you to do a check-up or touch you like they do at the clinic". Also, "with the ngangas you don't have to make an appointment, you just walk in whenever you have a problem and they will take care of you."

Table 18: $\quad$ Free scoring of different contraceptive methods from M'tendere

\begin{tabular}{|c|c|c|}
\hline $\begin{array}{l}\text { Contraceptive method } \\
\text { - Condoms }\end{array}$ & $\begin{array}{l}\text { Free scoring showing } \\
\text { the most common* } \\
48\end{array}$ & $\begin{array}{l}\text { Source } \\
\text { Bought at tuntembas (stalls) and } \\
\text { shops }\end{array}$ \\
\hline - $\quad$ Family planning pills & 28 & Clinic \\
\hline - One teaspoon of Muleza daily & 26 & $\begin{array}{l}\text { Roots obtained from women who } \\
\text { dig them up in the bush and charge } \\
\text { K2000 and up }\end{array}$ \\
\hline $\begin{array}{l}\text { - Four panadol tablets (to reduce } \\
\text { the power of a man's blood) }\end{array}$ & 13 & Buy from tunembas and shops \\
\hline - $\quad$ Abstain & 5 & \\
\hline
\end{tabular}

*the higher the score the more common the method

While the above group of girls indicated that abstaining from sex is the least common contraceptive method used, another group of girls felt that it was the most preferred because, according to them, it is the safest way to prevent pregnancy and STIs. Family planning pills were moderately scored because "they have a lot of adverse side effects and a woman can become barren if she continues to use pills for a long time". This group of girls also talked about the female condom and felt that this was a very good method since "it would help girls who don't want to be harassed by boys when they suggest using a condom." They also believed that they could use female condoms without having to tell their partner about them. They also mentioned that the female condom "was a better option [than the male condom] because it is the girl who uses them and she does not have to wait for the boy to agree to put it on". Finally, they felt that a female condom is safer than the male condom, because it remains in place during intercourse (unlike the male condom which can slip off) and because boys do not get the opportunity to prick or tear a hole in it. While they knew a great deal about the female condom, none of them had ever seen or used one. 


\section{Consequences of unprotected sex}

When out of school boys aged 12 - 19 years were talking about STIs one boy commented, "Yep, don't trust a girlfriend or you're gonna die like a chicken".

Extract from the field notes of Tamara Fetters

Although the prevalence of HIV and STIs is extremely high in Zambia, little is known about STIs in youth. In this research we set out to explore the knowledge and attitudes about sexually transmitted infections from the youth themselves.

Table 19: Prevalence of pregnancy and STIs

\begin{tabular}{|l|c|c|c|c|c|c|c|c|c|c|}
\cline { 2 - 10 } \multicolumn{1}{c|}{} & \multicolumn{2}{c|}{ M'tendere } & \multicolumn{2}{c|}{ New Kanyama } & \multicolumn{2}{c|}{ Misisi } & \multicolumn{2}{c|}{ Ngombe } & \multicolumn{2}{c|}{ TOTAL } \\
\cline { 2 - 10 } & $\begin{array}{c}\mathbf{M} \\
\mathbf{n}=\mathbf{1 4 2}\end{array}$ & $\begin{array}{c}\mathbf{F} \\
\mathbf{n = 8 0}\end{array}$ & $\begin{array}{c}\mathbf{M} \\
\mathbf{n = 1 6 8}\end{array}$ & $\begin{array}{c}\mathbf{F} \\
\mathbf{n = 1 1 3}\end{array}$ & $\begin{array}{c}\mathbf{M} \\
\mathbf{n = 1 8 9}\end{array}$ & $\begin{array}{c}\mathbf{F} \\
\mathbf{n}=\mathbf{1 3 8}\end{array}$ & $\begin{array}{c}\mathbf{M} \\
\mathbf{n = 1 5 7}\end{array}$ & $\begin{array}{c}\mathbf{F} \\
\mathbf{n = 1 0 9}\end{array}$ & $\begin{array}{c}\text { M } \\
\mathbf{n}=\mathbf{6 5 6}\end{array}$ & $\begin{array}{c}\mathbf{F} \\
\mathbf{n = 4 4 0}\end{array}$ \\
\hline $\begin{array}{l}\text { Percentage of } \\
\text { sexually active } \\
\text { adolescents who } \\
\text { have had an STI }\end{array}$ & 4 & 0 & 9 & 7 & 8 & 7 & 10 & 2 & 7.8 & 4.0 \\
\hline
\end{tabular}

As many as 10 percent of the boys interviewed during the survey in Ngombe Compound admitted to having had an STI though many of them did not believe that they were at risk for disease.

Q: What kind of people can get AIDS?

They believed that mahule (prostitutes) who go from bar to bar are the ones who are vulnerable and as for them, they couldn't be because they don't have many sperms.

A group of boys and girls aged $12-14$ yrs Extract from the field notes of Patrick Mwango

These adolescents are well aware of the symptoms of STIs that are common in their communities but still agreed that adolescents rarely have protected sex. The following chart produced by a group of 10-19 year-old boys from M'tendere Compound lists adolescent perceptions of STI symptoms and the names in vernacular. Bola-bola and syphilis are considered to be the most common STIs followed by kaswende and gonorrhea. Although not included in this chart, many adolescents also thought that tuberculosis was a sexually transmitted infection. 
Table 20: A chart of common STIs and symptoms created by a group of 1019 year-old boys from M'tendere

\begin{tabular}{ll}
\hline \multicolumn{1}{c}{ STIs } & \multicolumn{1}{c}{ Symptoms } \\
\hline Leaking (or linking) & -pus coming out from the penis or the vagina \\
& -sores around the penis or the vagina \\
\hline Bola Bola & -swelling around the testicles \\
& -swelling around the groin for man or woman \\
& -kuyenda dangaza (moving with the legs far apart) \\
\hline Syphilis & -the body structure of the man or woman affected by in it becomes \\
& abnormal, i.e. limbs become very small and the chest remains big \\
& -sores on the penis and the vagina \\
\hline Gonorrhea & Gave the same symptoms as leaking, and mentioned that it is the same \\
& STI \\
\hline Kalionde-onde (HIV/AIDS) & -rash on the body \\
& -eyes turn yellow \\
& -diarrhea \\
& -cough/fever/sneezing \\
& -great appetite \\
-weight loss \\
\hline Kaswende & -pain in the groin (male and female) \\
& -sores on the surface of the sexual organs \\
& -ulcers on the sexual organs \\
\hline
\end{tabular}

Our data show that adolescents suffering from symptoms of STIs usually seek help from a local healer or nganga. One group of 15-19 year-old boys from Misisi discussed their beliefs in the efficacy of traditional medicine especially when dealing with sexuality or reproductive health issues. They felt that 90 percent of adolescents suffering from symptoms of an STI would go to a nganga for help. The adolescents listed their complaints and reasons for not seeking treatment at the clinic:

- they had no money to pay for the National Health Insurance medical scheme required at the clinics

- they may be embarrassed or reprimanded by the nurses who know them

- they fear they will be asked to bring their sexual partners

- they are afraid of injections

- the clinic staff treats them poorly

- there is little privacy at the clinic so they are afraid of meeting neighbors and friends who may tell their parents they are seeking treatment

- some adolescents want to transmit the disease to others as "revenge"

- the clinic has no drugs and they are not able to afford filling a prescription at the pharmacist

Adolescents themselves were reluctant to discuss HIV/AIDS, even though we were discussing sexuality and reproductive health they rarely brought it up in conversations except in the classification of STIs. When we asked directly, however, most of the adolescents knew someone who had AIDS or had died of AIDS and knew how to prevent transmission of the infection. Still there was a pervasive stigma against these people living with AIDS and a reluctance to talk about the disease. 


\section{Table 21: $\quad$ Prevalence of pregnancy and STIs}

\begin{tabular}{|l|c|c|c|c|c|c|c|c|c|c|}
\cline { 2 - 9 } \multicolumn{1}{c|}{} & \multicolumn{2}{c|}{ M'tendere } & \multicolumn{2}{c|}{ New Kanyama } & \multicolumn{2}{c|}{ Misisi } & \multicolumn{2}{c|}{ Ngombe } & \multicolumn{2}{c|}{ TOTAL } \\
\cline { 2 - 9 } & $\begin{array}{c}\mathbf{M} \\
\mathbf{n}=\mathbf{1 4 2}\end{array}$ & $\begin{array}{c}\mathbf{F} \\
\mathbf{n}=\mathbf{8 0}\end{array}$ & $\begin{array}{c}\mathbf{M} \\
\mathbf{n}=\mathbf{1 6 8}\end{array}$ & $\begin{array}{c}\mathbf{F} \\
\mathbf{n}=\mathbf{1 1 3}\end{array}$ & $\begin{array}{c}\mathbf{M} \\
\mathbf{n = 1 8 9}\end{array}$ & $\begin{array}{c}\mathbf{F} \\
\mathbf{n = 1 3 8}\end{array}$ & $\begin{array}{c}\mathbf{M} \\
\mathbf{n = 1 5 7}\end{array}$ & $\begin{array}{c}\mathbf{F} \\
\mathbf{n}=\mathbf{1 0 9}\end{array}$ & $\begin{array}{c}\mathbf{M} \\
\mathbf{n}=\mathbf{6 5 6}\end{array}$ & $\begin{array}{c}\mathbf{F} \\
\mathbf{n}=\mathbf{4 4 0}\end{array}$ \\
\hline $\begin{array}{l}\text { Percentage of } \\
\text { sexually active } \\
\text { adolescents } \\
\text { who have made } \\
\text { someone /been } \\
\text { pregnant at } \\
\text { least once }\end{array}$ & 3 & 23 & 10 & 20 & 11 & 22 & 10 & 16 & 8.5 & 20.5 \\
\hline
\end{tabular}

Although many different ways to avoid pregnancy were mentioned by the girls involved in the research, more than 20 percent of the 10-19 year olds surveyed admitted to having been pregnant. Most of them felt that the actual use of any modern contraceptive method was very limited. One reproductive health decision that is usually made by girls is whether to abort a pregnancy or not. Most boys refuse responsibility for having fathered a child because they fear being tied down with responsibilities. At the same time if the boy agrees to having made a girl pregnant, he would be expected to pay for the 'damage' (a payment made to the girl's guardians for the expenses related to pregnancy and the upkeep of the child) if he does not marry her. If he does not pay or otherwise accept responsibility he may be threatened with witchcraft. Under such circumstances, it is easiest for the boy to deny having anything to with the pregnancy.

Few boys help girls they get pregnant by paying for an abortion or helping to get one done. The pregnant girl would usually seek help from her grandmother, friends or aunts to get rid of the pregnancy. Since most abortions are carried out secretly, various unsafe methods are used, most of them seem to be overdoses of toxic substances, modern medicines or some traditional recipes that are believed to be 'strong' and effective. The most common methods for inducing abortion were taking "red and black capsules" bought at the market and drinking muleza roots as a tea. Many adolescents also mentioned the use of sticks and sharp objects, that are pushed inside the vagina to induce abortion. In rare cases, especially where there is family support the girl gets an abortion done at a private clinic. As indicated by the chart below, created by a group of teenage girls from Misisi, knowledge about a variety of abortifacients was common amongst these adolescents, though they rarely mentioned legal abortion and were vague about the procedures required to get one. ${ }^{7}$

Under the Termination of Pregnancy Act in Zambia a legal abortion can be obtained if the mother, child or existing children's physical or mental health is in danger and the client has three doctor's signatures. A guardian's consent is required for girls under 16. There is a fee for these services. 
Table 22: A summary of methods for inducing an abortion

\begin{tabular}{ll}
\hline \multicolumn{1}{c}{ Method for inducing an abortion } & \multicolumn{1}{c}{ Procedure } \\
\hline Drinking red and black capsules & 6-10 capsules \\
\hline Drinking Panadol analgesic & 4-30 Panadol tablets with/without Coca-Cola \\
\hline Umunsoka nsoka & Bitter bark of a tree drunk as tea \\
\hline Boiled tea leaves & 1 cup \\
\hline Matamula & Elders prick you with a cassava stick \\
\hline Boom detergent & Swallow in large quantities \\
\hline Chloroquine & 10-20 tablets with/without Coca-Cola \\
\hline Some nurses assist at the clinic & Prick you with clinic equipment \\
\hline Cafenol & Drink 4 with Coca-Cola \\
\hline Cholera tablets & 4 tablets \\
\hline Muleza & Boil bark in water to make a tea \\
\hline Chidulo & Drink made from soda ash and salt (also before sex) \\
\hline Blue gum & Soak the leaves and drink as tea \\
\hline Itembusha & Cactus-like leaves made into tea \\
\hline Kankhalamba & Roots soaked and drunk as tea \\
\hline Mizyu za nyemba & Roots of a bean plant drunk as tea \\
\hline
\end{tabular}

Abortion was mentioned by both in and out of school girls and boys. These groups felt that abortions were being done for the following reasons:

- Girls want to continue with school

- Girls are afraid of disappointing their parents

- Boys refuse responsibility for the pregnancy

- Girls are afraid to become mothers

- Boys tells girls to abort

- The girl is still "playing" and does not want a baby

- The girl is afraid that she will not meet any more sex or marital partners if she has a child

- The male partner has no shelter (he cannot support the girl by asking her to live with him and the parents of the girl do not want to shoulder the burden of another household member)

Some girls believed that a girl's decision to have an abortion relates to her age. They generally felt that a younger girl would be more likely to have an abortion than an older girl. When asked what a "small size" girl (approximately 12 years old) will do if she becomes pregnant, the majority of the girls felt that the girl would abort rather than keep the child. When the girls were asked what a 14 year-old would do if she became pregnant, they said she would most likely get married (forced by parents) or keep the baby.

\section{Seeking solutions}

PLA is particularly useful when designing or refining interventions as it encourages the community to propose solutions to the problems they identify. The youth who participated in these PLAs provided ideas on how to increase the utilization of clinics by adolescents, acceptable channels of education, and how to support youth to resist engaging in risky sexual behavior. 
For example, suggestions to improve clinic utilization by adolescents were put forward by two groups of boys in M'tendere:

- The "medical scheme" (Zambian National cost recovery program) should be abolished

- The nurses at the clinic should not insult the boys who visit the clinic for treatment of STIs

- Clinic staff should stop eating while attending to patients

- Have more doctors at the clinic in order to reduce congestion

- Clinic staff should prescribe the correct treatments

- Clinic staff should not "hide" medicines

- Privacy and confidentiality should be assured

When asked what amenities and services they would like to see in the compounds the teens all pointed out the need for schools and clinics in the compound. These adolescents felt that many of their problems stemmed from a lack of activities that encourages young people to steal or gamble. We asked them what would change in the lifestyle of the adolescents if a school were built in a compound. They felt that ukawalala (robberies or thieving) would be reduced, educational standards would improve and the technical skills among adolescents would increase by fostering selfreliance among themselves. School halls would be available for children to watch educational films, documentaries and cartoons as opposed to young people only watching adult sexual and violent movies. Prostitution would decrease since girls would have less time to meet their boyfriends.

\section{Feeding back to the community}

After the PLAs were held and the data synthesized by a core group of researchers, a number of dissemination workshops were held in each community. The communitybased researchers who were involved in the fieldwork (usually providers and Neighborhood Health Committee members) presented the results to adults in a neighborhood meeting to give the communities a sense of ownership and add credibility to some of the more sensitive results. After a dissemination was held with adults, additional dissemination meetings were held with adolescents who participated in the PLAs and some who did not. Key findings on sexuality, knowledge and common misperceptions were presented to the young people and they were asked to develop community action plans. Almost all of their suggestions were centered around more recreational and economic opportunities for themselves and their peers. These action plans helped us to tailor our interventions to their own ideas and suggestions and gain support for our programs. The adolescents involved in the dissemination meetings were asked to organize their own peer groups and thus begin the selfselection and recruitment process for the interventions. 


\section{Conclusions}

PLA research yields relatively quick and low-cost results useful for program design and implementation. During the research we talked to hundreds of adolescents about sexuality and reproductive health and gave them an opportunity to look at their own lives (and the lives of their peers) and identify potential solutions to their own problems. Often we would find adolescents waiting for us at the meeting place wanting to take part and share with us their own thoughts and feelings.

It is clear from this research that environment contributes to poor sexual and reproductive health. In these compounds adolescents live in crowded environs where people do not disguise or try to hide their sexual activity. These communities have no recreational facilities and few economic opportunities other than small scale vending and trading for sex in the surrounding taverns. Sexual activity begins as early as eight years of age and can be either forced or consensual. Reliable sources of information on sexual health in the early years are almost nonexistent and sex as a bartering tool is deeply embedded in these adolescents' lives.

Household living situations also play a role in an adolescent's sexual behavior. In these households sexual relations amongst neighbors and relatives (especially cousins and in-laws) are common, maybe even expected. Subsequently, adolescents get most of their "sex education" from observation, film and media, and friends; they are least likely to discuss these problems with parents and clinicians. All of their sources of information are ripe for the inaccuracies and misperceptions that are common in the compound.

These adolescents prefer to buy (if they have money) traditional or modern contraceptives rather than go to the health center. Regarding contraception, they hold strong beliefs in the efficacy of traditional contraceptive methods, abortifacients and tablets and capsules sold to them by local marketers. Adolescents are even more reluctant to go to a health center for treatment of an STI. Most of the adolescents we spoke with could only name two modern contraceptive methods ("pills" and condoms, although condoms were more often associated with protection from disease rather than pregnancy) and their knowledge of STIs often confused symptoms commonly associated with the diseases. The adolescents had an abundance of information on traditional (and often harmful) methods for inducing an abortion at home, in a private clinic or with the help of a traditional medical practitioner.

Peer pressure, "young love", pornographic film and economics all play a role in increasing sexual activity in this compound. The early ages of sexual initiation put young people at a greater risk of STI both physiologically and because of the increasing number of partners in their lifetime. Most sex in this area is "paid for". Economic needs for school and survival are great, "payment" or exchanges for sex begin early and becomes commonplace. Schoolchildren often trade sex for pencils, snacks or test answers. Early sexual activity is common amongst in and out of school boys and girls; in school girls have even more economic needs than out of school girls 
but they lack the vending opportunities open to the young school leavers. Although girls occasionally give gifts or money to male sex partners, all of the girls said that they preferred boyfriends who "could pay something".

Adolescents hold a general disdain for condoms even though they are aware that condoms prevent disease and pregnancy. Boys feel that condoms are too big for them, they prefer "skin-to-skin" sex and do not feel at risk of acquiring STIs or AIDS. Girls rarely initiate condom use for fear a boy will think she is "sick" or because the boys claim that they do not trust or love him. If a girl wants to use a condom, the girls complain that boys will "prick the condoms" to get them pregnant because the girls were arrogant enough to demand condom use. Some young boys and girls believe that a young boy cannot impregnate a girl because his "sperms are not strong enough". Perhaps, in part, because of this belief condom use increases in the mid to late teens except in the case of young female partners when older boys are said to be looking for "young clean girls".

The suggestions of the adolescents were clear: "invest in us and invest in our communities". They listed improvements in infrastructure (schools, clinics, garbage collection, and recreation facilities) as well as interventions that would affect their own lives (vocational training and starter capital for projects). These adolescents clearly saw their environment as having an effect on their sexual and reproductive health and reaffirm the need for more integrated reproductive health programming that addresses not only health but also economic development and skill-building. 